\title{
PENGARUH FLUKTUASI IHSG, INFLASI DAN SUKU BUNGA TERHADAP IMBAL HASIL UNITLINK BERBASIS SAHAM
}

\author{
Teguh Antolis ${ }^{1}$; Samuel Dossugi ${ }^{2}$
}

\begin{abstract}
Investment is a general word and is understood by the general society, but how to manage an investment or how to invest the money that will generate good return with small risk is an attractive challenge and not known by many people. This paper will discuss about unit link, a newly developed investment instrument, which is predicted to be the new star for investment, together with the factors that influence the return of a unit link investment. Unit link is an innovation from the financial industry, and is a combination of insurance and investment. Year 2007 is the year where the stock market had a spectacular growth and this paper will discuss the IHSG fluctuation phenomenon, inflation and interest rate toward the equity-based unit link return and the effect of each factors. From the result of research, we can conclude that IHSG, inflation and interest will affect the equity-based unit link return where the most significant effect is shown by IHSG.
\end{abstract}

Keywords: unit link, investment, return, IHSG, inflation, interest rate

\begin{abstract}
ABSTRAK
Investasi adalah suatu kata yang umum dan sudah dimengerti oleh masyarakat luas, namun bagaimana mengelola suatu investasi atau bagaimana meng-investasi-kan dana yang dimiliki sehingga beroleh suatu imbal hasil yang menarik dan dibarengi dengan risiko yang kecil adalah suatu tantangan yang menarik dan belum diketahui oleh banyak orang. Tulisan ini akan membahas mengenai unitlink, suatu instrumen investasi yang baru berkembang dan diharapkan dapat menjadi primadona baru untuk dapat dijadikan alternatif untuk melakukan investasi serta faktor - faktor yang mempengaruhi imbal hasil dari unitlink tersebut Unitlink sendiri adalah suatu inovasi di dunia keuangan berupa gabungan antara asuransi dan investasi.

Tahun 2007 merupakan tahun di mana pasar saham mengalami perkembangan yang luar biasa, tulisan ini akan mencoba mengkaji fenomena fluktuasi IHSG, Inflasi dan suku bunga terhadap imbal hasil unitlink berbasis saham dan bagaimana pengaruh masing-masing faktor tersebut.

Dari hasil penelitian didapatkan kesimpulan bahwa IHSG, Inflasi dan suku bunga ternyata mempengaruhi imbal hasil unitlink berbasis saham di mana pengaruh paling signifikan ditunjukkan oleh IHSG
\end{abstract}

Kata kunci : unitlink, investasi, imbal hasil, IHSG, inflasi, suku bunga

\footnotetext{
1,2 BINUS BUSINESS SCHOOL, BINUS UNIVERSITY, JWC Campus, Jl. Hang Lekir I No. 6, Kebayoran Baru, South Jakarta 12120, dossugi@hotmail.com
} 


\section{PENDAHULUAN}

Investasi adalah suatu hal yang sangat dicita-citakan masyarakat pada umumnya agar bertambahlah harta yang dimiliki oleh masyarakat tersebut. Macam-macam instrumen investasi yang ada di masyarakat pada umumnya hanya berkisar pada instrumen-instrumen yang umum dan telah banyak dikenal seperti tanah, rumah, emas, deposito, dll.

Seiring dengan berkembangnya jaman, maka perkembangan di bidang keuangan khususnya di bidang investasi pun semakin marak, dengan bermunculannya macam-macam instrumen investasi yang bisa jadi malah menimbulkan kebingungan yang tentunya tidak terlalu mudah juga dipahami oleh masyarakat awam.

Salah satu bentuk investasi yang belum begitu banyak dikenal masyarakat adalah unitlink. Di mana unitlink ini adalah sebuah kombinasi antara asuransi dengan investasi dan unitlink ini nantinya akan dikelola oleh Manajer Investasi yang diberikan tanggung jawab untuk mengelola dana dari masyarakat/nasabah tersebut dengan mengupayakan untuk mendapatkan keuntungan yang maksimal.

Melihat dari cara kerja yang dilakukan oleh para perusahaan asuransi yang sekaligus bertindak sebagai Manajer Investasi untuk investasi nasabah tersebut, adalah sangat mirip dengan Reksa Dana yang sudah umum dikenal oleh masyarakat. Tulisan ini akan mencoba mengupas lebih mendalam mengenai unitlink ini di mana perbedaan antara Reksa Dana dengan unitlink adalah sebuah pertanyaan yang sangat mungkin akan ditanyakan oleh banyak orang yang awam akan dunia investasi. Seperti kita sudah ketahui pada umumnya bahwa masyarakat awam sendiri masih banyak yang belum mengetahui apa itu investasi walaupun kalau diadakan survei atau angket bisa dipastikan akan banyak yang menjawab mereka perlu akan investasi tapi tidak tahu apa yang harus dilakukan dengan investasi tersebut.

Setiap individu menginginkan adanya sebuah jaminan kepastian akan masa depannya yang mana hal ini sudah dikenal sejak dari jaman dahulu kala, sehingga cara yang ditempuh masyarakat pada umumnya adalah dengan menabung baik ditabung pada diri sendiri ( tidak menghasilkan bunga ) maupun ditabung pada lembaga/institusi tertentu seperti bank.

Namun sesuai dengan sifat dasar manusia yaitu sangat sulit untuk mendisiplinkan diri maka untuk melakukan menabung ini menjadi sebuah hal yang sangat sulit dilakukan, Terlebih lagi seperti yang sudah kita ketahui juga bahwa untuk masa sekarang di mana kehidupan yang dijalani semakin sulit dan makin bertambah sulit setiap hari.Berita inflasi, kenaikan harga-harga semakin membuat pusing dan membuat kita berpikir keras akan masa depan. Kekhawatiran akan semakin menghantui setiap individu akan masa depannya terlebih lagi bagi mereka yang sudah berkeluarga. Khawatir akan masa tua atau masa pensiun di mana aktivitas pasti sudah jauh berkurang dan kemampuan akan mulai menurun, sehingga dalam masa-masa tersebut yang disebut juga dengan usia tidak produktif namun masih membutuhkan banyak biaya untuk bertahan hidup. Ditambah lagi bagi mereka yang sudah mempunyai anak, pastilah mengalami kekhawatiran akan masa depan genarasi penerus mereka yaitu anak-anak mereka.Makin bertambahnya kebutuhan menyebabkan manusia akan semakin sadar akan perlunya mereka untuk berinvestasi. Salah satu kebutuhan yang sangat penting dan biayanya makin meningkat setiap tahunnya adalah kebutuhan akan pendidikan.

Hal-hal semacam di atas inilah yang ditangkap oleh perusahaan - perusahaan asuransi jiwa yang melihat hal ini sebagai sebuah peluang emas untuk memasarkan produk-produk mereka. Di antara begitu banyak produk asuransi yang dikeluarkan oleh perusahaanperusahaan asuransi pada umumnya adalah produk-produk konvensional yang bisa dibilang 
hanya memberikan perlindungan semata bagi nasabah asuransi tanpa adanya keterlibatan nasabah secara aktif.

Sedangkan Unitlink, sebuah produk asuransi yang merupakan gabungan antara asuransi dan investasi adalah sebuah produk yang boleh dibilang masih belum begitu lama diperkenalkan di masyarakat Indonesia dan baru mulai marak belakangan ini. Walapun di luar negeri khususnya di Amerika Serikat, Unitlink sudah lama dikenal tapi di Indonesia hal ini masih dipandang baru dan masih sangat awam dikenal. Untuk saat-saat sekarang ini Unitlink sudah amat sangat menjamur di Indonesia, dan mulai ramai dibicarakan. Makin hari makin banyak produk-produk unitlink yang mulai dikeluarkan perusahaan-perusahaan asuransi untuk menarik minat masyarakat. Gayung bersambut, masyarakat menyambut hal ini dengan sangat antusias di mana banyak sekali perusahaan asuransi yang porsi pendapatan terbesar mereka berasal dari unitlink.

Adalah merupakan kebutuhan juga bagi masayarakat sebagi investor untuk dapat menentukan jenis investasi dengan unitlink ini yang dianggap menghasilkan atau memberikan imbal hasil yang maksimal. Dari beberapa jenis unitlink yang ada, penulis mengambil unitlink berbasiskan saham dengan pertimbangan Unitlink berbasis saham adalah unitlink yang memberikan imbal hasil terbesar, dan akan dikupas lebih mendalam pada penulisan selanjutnya mengenai faktor-faktor yang mempengaruhi imbal hasil dari unitlink tersebut..

\section{RUMUSAN PERMASALAHAN}

Di balik maraknya perkembangan unitlink yang malah bagi sebagian besar perusahaan asuransi sudah menjadi pemasukan utama ada sebuah pertanyaan yang bisa diajukan oleh orang awam sekalipun, yaitu : Bagaimana imbal hasil yang didapatkan dengan berinvestasi di unitlink ? Apa sajakah faktor-faktor yang mempengaruhi imbal hasil atau return yang diharapkan dan bagaimana pengaruh dari masing-masing faktor tersebut?

Penulis mengambil beberapa faktor yang akan coba diangkat dalam penelitian ini, yaitu : Indeks Harga Saham Gabungan ( IHSG ) yang dianggap mewakili kondisi pasar, tingkat inflasi dan tingkat suku bunga yang diterbitkan oleh Bank Indonesia.

Fokus dari penelitain ini adalah : Bagaimana pengaruh fluktuasi pasar ( IHSG ), tingkat inflasi dan suku bunga terhadap imbal hasil produk unitlink berbasis saham.

Hipotesis : Terdapat pengaruh yang signifikan dari fluktuasi pasar yang dicerminkan oleh IHSG terhadap imbal hasil produk unitlink berbasis saham

\section{LANDASAN TEORI}

Perasuransian di Indonesia diatur dengan Undang-Undang Nomor 2 tahun 1992 tentang usaha perasuransian. Sebelum diundangkannya undang-undang usaha perasuransian, kegiatan perasuransian di Indonesia hanya diatur dengan Keputusan Menteri Keuangan dan Ordonantie op het Levensverzkering bedriff ( Staatsblad 1941 No 101 ).

Jenis usaha perasuransian yang diatur dalam Undang-undang Nomor 2 tahun 1992 dapat digolongkan sebagai berikut : 
- Usaha asuransi yang terdiri atas asuransi kerugian ( non life insurance ), asuransi jiwa ( life insurance ) dan reasuransi ( resinsurance )

- usaha penunjang asuransi yang terdiri atas : pialang asuransi, pialang reasuransi, penilai kerugian, konsultan aktuaria dan agen asuransi.

Asuransi Jiwa adalah suatu jasa yang diberikan oleh perusahaan asuransi dalam penanggulangan risiko yang dikaitkan dengan jiwa atau meninggalnya seseorang yang dipertanggungkan. Berdasar ketentuan perundangan, hanya perusahaan asuransi jiwa yang telah memperoleh izin usaha dari Menteri Keuangan yang dapat melakukan kegiatan pertanggungan jiwa. Oleh karena itu, asuransi kerugian tidak diperkenankan melakukan kegiatan penutupan dalam bidang asuransi jiwa.

Pengertian asuransi menurut Kitab undang-undang Hukum Dagang pasal 246:

Asuransi atau pertanggungan adalah suatu perjanjian, dengan mana seseorang penanggung mengikatkan diri kepada seorang tertanggung, dengan menerima suatu premi untuk memberikan penggantian kepadanya karena suatu kerugian, kerusakan, atau kehilangan keuntungan yang diharapkan, yang mungkin terjadi karena suatu peristiwa tak tertentu.

Pengertian asuransi menurut undang-undang no. 2 tahun 1992 tentang usaha perasuransian :

Asuransi atau pertanggungan adalah perjanjian antara dua pihak atau lebih, dengan mana pihak penanggung mengikatkan diri kepada tertanggung, dengan menerima premi asuransi, untuk memberikan penggantian kepada tertanggung karena kerugian, kerusakan, atau kehilangan keuntungan yang diharapkan, atau tanggung jawab hukum kepada pihak ke tiga yang mungkin akan diderita tetanggung, yang timbul dari suatu peristiwa yang tidak pasti, atau untuk memberikan suat pembayaran yang didasarkan atas meninggal atau hidupnya seseorang yang dipertanggungkan.

Pada prinsipnya manusia menghadapi 4 macam ketidakpastian yang berkatian dengan produktivitas ekonomisnya, yaitu : kematian, cacat, pemutusan hubungan kerja, dan pengangguran. Dalam menghadapi kemungkinan ketidakpastian tersebut, asuransi jiwa merupakan instrumen finansial untuk :

1. memberikan dukungan bagi pihak yang selamat dari suatu kecelakaan

2. membayar santunan bagi tertanggung yang meninggal

3. membantu usaha dari kerugian yang disebabkan meninggalnya pejabat kunci perusahaan

4. penghimpunan dana untuk persiapan pensiun, keperluan penting, dan penggunaan untuk bisnis

5. menunda atau menghindari pajak pendapatan.

Jenis-jenis polis asuransi jiwa

1. Term

2. Endowment

3. Whole Life dan Universal Life

4. Annuity contract

\section{Term Insurance}

Asuransi berjangka atau term insurance mewajibkan penanggung untuk membayar jumlah nominal polis apabila tertanggung meninggal dalam suatu periode tertentu. 
Apabila tertanggung tetap hidup sampai jangka waktu yang ditetapkan dalam polis, maka kontrak berakhir dengan tanpa nilai. Masalah pokok yang membedakan dan penting dalam jenis asuransi jiwa ini dengan asuransi jiwa lainnya adalah mengenai kontrak yang memiliki periode tetap/pasti dan memiliki nilai tunai yang sangat kecil atau bahkan nilai tunainya tidak ada sama sekali

Term insurance atau asuransi berjangka terdiri atas :

- Straight term insurance, yaitu asuransi yang berjangka waktu satu atau beberapa tahun dan berakhir pada periode yang telah ditetapkan. Jangka waktu polis yang dimulai dari $1,5,10$, atau 20 tahun dan berakhir pada umur 65 atau 70 tahun merupakan jenis polis yang cukup populer.

- Renewable term insurance memungkinkan pemilik polis untuk memperpanjang polis sebelum jangka waktunya berakhir tanpa perlu membuktikan atau memenuhi kembali persyaratan, seperti pembuktian kesehatan tertanggung dalam keadaan baik yang biasanya dalam bentuk pernyataan sehat dari dokter ( insurability ).

- Yearly renewable term pada prinsipnya merupakan bentuk asli dari asuransi berjangka. Atas opsi dari pemilik tanpa perlu pembuktian insurability, polis dapat diperpanjang setiap tahun, fasilitas perpanjangan tersebut terbatas sampai jangka waktu tertentu atau sampai dengan umur tertentu, sersuai dengan jangka waktu berakhir kontrak. Umumnya asurader membatasi perpanjangan tersebut pada umur 65 atau 70 tahun.

- Convertible term memungkinkan polis untuk dikonversi menjadi program lainnya misalnya, program asuransi seumur hidup, endowment - dalam suatu periode tertentu tanpa pembuktian insurability. Dalam hal ini, beberapa perusahaan asuransi jiwa meniadakan kemungkinan konversi oleh pemilik polis dengan cara menawarkan convertible term otomatis sebagai suatu opsi, yaitu konversi otomatis tersebut dinyatakan pada suatu tanggal tetentu dalam polis. Polis renewable dan convertible dapat digabung ke dalam suatu polis yang disebut dengan renewable and convertible term. Misalnya, polis dapat diperpanjang sampai 70 tahun dan dapat dikonversi sebelum umur 65 tahun.

Bentuk umum dari term insurance ini adalah level term, yaitu jumlah pembayaran premi tetap sama selama periode berjalan. Di samping itu, dikenal pula bentuk increasing dan decreasing term insurance. Decreasing term, yaitu jumlah nominal polis berkurang secara periodik, misalnya, secara bulanan atau tahunan. Polis ini berguna bagi orang tua untuk menyediakan proteksi dengan biaya rendah sementara anak-anaknya masih kecil,. Incerasing term memberikan pertanggungan yang mengalami kenaikan secarta bulanan atau tahunan. Polis ini digunakan sebagai proteksi terhadap inflasi. Baik increasing maupun decreasing data ditambahkan sebagai rider terhadap polis-polis whole life dan endowment. Karena kemungkinan meningkatnya kematian berbanding lurus dengan bertambahnya umur, jumlah premi naik secara bertahap sejalan dengan bertambahnya umur tertanggung. Namun, pada umur-umur lanjut pembayaran premi mengalami kenaikan yang cukup besar untuk mencerminkan kemungkinan tingkat kematian yang lebih tinggi. Untuk membebaskan pemilik polis membayar premi yang semakin naik, term insurance ditawarkan dengan bentuk levelpremium plan di mana premi tetap sama besarnya setiap tahun selama masa berlakunya polis. Premi untuk polis convertible dan renewable term biasanya relatif lebih tinggi. 


\section{Endowment Insurance.}

Endowment Insurance mewajibkan penanggung untuk membayar pihak tertanggung atau keluarga tertanggung ( beneficiary ) sejumlah uang kepada pemegang polis apabila tertanggung tetap hidup selama periode pertanggungan. Misalnya, polis asuransi endowment untuk jangka waktu 20 tahun dengan nilai sebesar Rp 20 juta. Perusahaan asuransi akan membayar sejumkah Rp 20 juta kepada keluarga tertanggung apabila dalam periode pertanggungan tersebut tertanggung meninggal dunia, atau akan dibayarkan kepada tertanggung apabila ia tetap hidup sampai pada akhir periode pertanggungan. Oleh karena itu, premi jenis pertanggungan ini biasanya lebih tinggi dibandingkan dengan harga polis term insurance. Karena dapat dianggap sebagai program tabungan yang dilindungi dengan asuransi jiwa. Di samping itu, karena asuransi tersebut menekankan pengumpulan tabungan, maka dapat juga berfungsi atau digunakan sebagai dana untuk membiayai masa pensiun. Sehubungan dengan sifat polis ini, perusahaan asuransi harus mengenakan premi dalam jumlah yang memadai untuk memenuhi pembayaran apabila telah jatuh tempo.

\section{Whole Life insurance}

Asuransi seumur hidup atau whole life insurance, juga dikenal dengan asuransi nilai tunai atau nilai permanent, menawarkan perlindungan selama masa hidup tertanggung. Polis asuransi ini dapat dipandang sebagai suatu asuransi endowment untuk umur 100 tahun atau berjangka waktu sampai mencapai umur 100 tahun. Penentuan tingkat kematian tersebut dilakukan dengan menggunakan suatu daftar yang disebut Tabel Mortalita. Tabel ini menunjukkan jumlah orang yang diperkirakan akan meninggal pada saat umur mereka mencapai jumlah tertenu. Tabel Mortalita merupakan alat untuk menghitung dan menentukan tarif asuransi jiwa. Tabel tersebut mengasumsikan semua orang akan meninggal sebelum mencapai ulang tahunnya yang ke -100 . Selanjutnya, bagi mereka yang mencapai umur 100 tahun akan dibayar sebesar nilai polis karena mereka dapat tetap hidup sampai umur maksim,um yang ditetapkan oleh aktuaris. Dengan alasan-alasan tersebut, asuransi polis whole life dapat dipandang sebagai suatu endowment yang jatuh temponya pada saat umur mencapai 100 tahun.

\section{Annuity}

Anuitas atau annuity menyediakan suatu pemasukan secara periodic dan teratur bagi tertanggung untuk suatu periode tertentu. Anuitas yang menyediakan pendapatan selama hidup disebut life annuity. Anuitas meruopakan instrument yang penting dalam perencanaan untuk jaminan financial selama menjalankan masa pensiun.

\section{Investasi}

Menurut Eko Priyo Pratomo dan Ubaidillah Nugraha (2005), dalam bukunya, Reksa Dana : Solusi Perencanaan Investasi di Era Modern, Ada 3 hal utama yang mendasari perlunya seseorang melakukan investasi, yaitu:

1) Adanya kebutuhan masa depan atau kebutuhan saat ini yang belum mampu untuk dipenuhi saat ini. 
2) Adanya keinginan untuk menambah nilai asset, adanya kebutuhan untuk melindungi nilai asset yang sudah dimiliki.

3) Berkaitan dengan adanya inflasi.

Dari definisi diatas maka, investasi dapat didefinisikan sebagai suatu komitmen pada dana-dana dari satu atau lebih asset yang akan dipegang untuk periode yang akan datang. Jadi, investasi pada dasarnya adalah "membeli" suatu asset yang diharapkan di masa mendatang untuk dapat "dijual kembali" dengan nilai yang lebih tinggi.

\section{Pasar Modal}

Undang-Undang Pasar Modal No. 8 tahun 1995 tentang Pasar Modal mendefinisikan pasar modal sebagai "kegiatan yang bersangkutan dengan Penawaran Umum dan perdagangan Efek, Perusahaan Publik yang berkaitan dengan Efek yang diterbitkannya, serta lembaga dan profesi yang berkaitan dengan Efek". Pasar Modal memiliki peran penting bagi perekonomian suatu negara karena pasar modal menjalankan dua fungsi, yaitu pertama sebagai sarana bagi pendanaan usaha atau sebagai sarana bagi perusahaan untuk mendapatkan dana dari masyarakat pemodal (investor). Dana yang diperoleh dari pasar modal dapat digunakan untuk pengembangan usaha, ekspansi, penambahan modal kerja dan lain-lain, kedua pasar modal menjadi sarana bagi masyarakat untuk berinvestasi pada instrument keuangan seperti saham, obligasi, reksa dana, dan lain-lain. Dengan demikian, masyarakat dapat menempatkan dana yang dimilikinya sesuai dengan karakteristik keuntungan dan risiko masing-masing instrument.

\section{Indeks Harga Saham}

Indeks harga saham adalah suatu indikator yang menunjukkan pergerakan harga saham. Indeks berfungsi sebagai indikator trend pasar, artinya pergerakan indeks menggambarkan kondisi pasar pada suatu saat, apakah pasar sedang aktif atau lesu. Dengan adanya indeks, kita dapat mengetahui trend pergerakan harga saham saat ini; apakah sedang naik, stabil atau turun. Misal, jika di awal bulan nilai indeks 300 dan saat ini di akhir bulan menjadi 360, maka kita dapat mengatakan bahwa secara rata-rata harga saham mengalami peningkatan sebesar $20 \%$. Pergerakan indeks menjadi indikator penting bagi para investor untuk menentukan apakah mereka akan menjual, menahan atau membeli suatu atau beberapa saham. Karena harga-harga saham bergerak dalam hitungan detik dan menit, maka nilai indeks pun bergerak turun naik dalam hitungan waktu yang cepat pula.

Di Bursa Efek Indonesia terdapat beberapa jenis indeks, antara lain:

1. Indeks Individual, menggunakan indeks harga masing-masing saham terhadap harga dasarnya, atau indeks masing-masing saham yang tercatat di BEI.

2. Indeks Harga Saham Sektoral, menggunakan semua saham yang termasuk dalam masing-masing sektor, misalnya sektor keuangan, pertambangan, dan lain-lain. Di BEI indeks sektoral terbagi atas sembilan sektor yaitu: pertanian, pertambangan, industri dasar, aneka industri, konsumsi, properti, infrastruktur, keuangan, perdagangan dan jasa, dan manufaktur.

3. Indeks Harga Saham Gabungan atau IHSG (Composite Stock Price Index), menggunakan semua saham yang tercatat sebagai komponen penghitungan indeks.

4. Indeks LQ 45, yaitu indeks yang terdiri 45 saham pilihan dengan mengacu kepada 2 variabel yaitu likuiditas perdagangan dan kapitalisasi pasar. Setiap 6 bulan terdapat saham-saham baru yang masuk kedalam LQ 45 tersebut. 
5. Indeks Syariah atau JII (Jakarta Islamic Index). JII merupakan indeks yang terdiri 30 saham mengakomodasi syariat investasi dalam Islam atau Indeks yang berdasarkan syariah Islam. Dengan kata lain, dalam Indeks ini dimasukkan saham-saham yang memenuhi kriteria investasi dalam syariat Islam. Saham-saham yang masuk dalam Indeks Syariah adalah emiten yang kegiatan usahanya tidak bertentangan dengan syariah seperti:

- Usaha perjudian dan permainan yang tergolong judi atau perdagangan yang dilarang.

- Usaha lembaga keuangan konvensional (ribawi) termasuk perbankan dan asuransi konvensional.

- Usaha yang memproduksi, mendistribusi serta memperdagangkan makanan dan minuman yang tergolong haram

- Usaha yang memproduksi, mendistribusi dan/atau menyediakan barangbarang ataupun jasa yang merusak moral dan bersifat mudarat

6. Indeks Papan Utama dan Papan Pengembangan. Yaitu indeks harga saham yang secara khusus didasarkan pada kelompok saham yang tercatat di BEI yaitu kelompok Papan Utama dan Papan Pengembangan.

7. Indeks KOMPAS 100. merupakan Indeks Harga Saham hasil kerjasama Bursa Efek Indonesia dengan harian KOMPAS. Indeks ini meliputi 100 saham dengan proses penentuan sebagai berikut :

- Telah tercatat di BEJ minimal 3 bulan.

- Saham tersebut masuk dalam perhitungan IHSG (Indeks Harga Saham Gabungan).

Berdasarkan pertimbangan faktor fundamental perusahaan dan pola perdagangan di bursa, BEI dapat menetapkan untuk mengeluarkan saham tersebut dalam proses perhitungan indeks harga 100 saham.

Masuk dalam 150 saham dengan nilai transaksi dan frekwensi transaksi serta kapitalisasi pasar terbesar di Pasar Reguler, selama 12 bulan terakhir.

Dari sebanyak 150 saham tersebut, kemudian diperkecil jumlahnya menjadi 60 saham dengan mempertimbangkan nilai transaksi terbesar.

Dari sebanyak 90 saham yang tersisa, kemudian dipilih sebnyak 40 saham dengan mempertimbangkan kinerja: hari transaksi dan frekwensi transaksi serta nilai kapitalisasi pasar di pasar reguler, dengan proses sebagai berikut :

i. Dari 90 sisanya, akan dipilih 75 saham berdasarkan hari transaksi di pasar reguler.

ii. Dari 75 saham tersebut akan dipilih 60 saham berdasarkan frekuensi transaksi di pasar reguler.

iii. Dari 60 saham tersebut akan dipilih 40 saham berdasarkan Kapitalisasi Pasar.

Daftar 100 saham diperoleh dengan menambahkan daftar saham dari hasil perhitungan butir (e) ditambah dengan daftar saham hasil perhitungan butir Daftar saham yang masuk dalam KOMPAS 100 akan diperbaharui sekali dalam 6 bulan, atau tepatnya pada bulan Februari dan pada bulan Agustus. 


\section{Unitlink}

Berdasarkan Keputusan Ketua Badan Pengawas Pasar Modal Dan Lembaga Keuangan Nomor KEP-104/BL/2006 Tentang Produk Unitlink :

1. Produk unit link adalah produk asuransi jiwa yang memenuhi kriteria sebagai berikut:

a. nilai manfaat yang dijanjikan ditentukan oleh kinerja subdana investasi yang dibentuk untuk unit link tersebut;

b. nilai manfaat yang diperoleh dari subdana investasi dinyatakan dalam unit; dan

c. mengandung pertanggungan risiko kematian alami.

2. Produk unit link sebagaimana dimaksud dalam angka 1 wajib memenuhi ketentuan sebagai berikut:

a. besar uang pertanggungan kematian alami untuk polis dalam mata uang rupiah sekurang-kurangnya sebesar:

1) yang lebih besar di antara $\mathrm{Rp} 15.000 .000$ (lima belas juta rupiah) dengan $125 \%$ (seratus dua puluh lima per seratus) dari premi sekaligus, untuk polis dengan pembayaran premi sekaligus; atau

2) yang lebih besar di antara $\mathrm{Rp} 7.500 .000$ (tujuh juta lima ratus ribu rupiah) dengan 5 (lima) kali premi tahunan, untuk polis dengan pembayaran premi berkala;

b. besar uang pertanggungan kematian alami untuk polis dalam mata uang asing sekurang-kurangnya:

1) yang lebih besar di antara US $\$ 1,500$ (seribu lima ratus dolar Amerika Serikat) atau yang setara dengan itu untuk mata uang asing lainnya dengan $125 \%$ (seratus dua puluh lima per seratus) dari premi sekaligus, untuk polis dengan pembayaran premi sekaligus; atau

2) yang lebih besar di antara US\$750 (tujuh ratus lima puluh dolar Amerika Serikat) atau yang setara dengan itu untuk mata uang asing lainnya dengan 5 (lima) kali premi tahunan, untuk polis dengan pembayaran premi berkala;

c. masa pertanggungan asuransi sekurang-kurangnya 5 (lima) tahun.

3. Nama dan Strategi Investasi Produk Unit Link

a. Perusahaan Asuransi Jiwa dilarang memberikan nama suatu produk unit link dengan nama yang dapat mengakibatkan interpretasi yang berbeda dari strategi investasinya.

b. Strategi investasi untuk unit link dapat berupa:

1) Strategi investasi pasar uang, apabila perusahaan asuransi jiwa melakukan investasi aset subdana pada surat berharga bersifat utang dengan jatuh tempo kurang dari 1 (satu) tahun dan atau Unit Penyertaan Reksa Dana Pasar Uang.

2) Strategi investasi pendapatan tetap, apabila perusahaan asuransi jiwa melakukan investasi sekurang-kurangnya $80 \%$ (delapan puluhperseratus) dari aset subdana dalam bentuk surat berharga 
bersifat utang dan atau Unit Penyertaan Reksa Dana Pendapatan Tetap.

3) Strategi investasi saham, apabila perusahaan asuransi jiwa melakukan investasi sekurang-kurangnya $80 \%$ (delapan puluh perseratus) dari aset subdana dalam saham dan atau Unit Penyertaan Reksa Dana Saham.

4) Strategi investasi campuran, apabila perusahaan asuransi jiwa melakukan investasi aset subdana dalam surat berharga bersifat utang dan saham yang perbandingannya tidak sebagaimana dimaksud dalam butir 2) atau butir 3), dan atau Unit Penyertaan Reksa Dana Campuran.

5) Strategi investasi syariah, apabila perusahaan asuransi jiwa melakukan investasi aset subdana seluruhnya pada surat berharga syariah.

c. Perusahaan asuransi jiwa wajib membentuk subdana untuk setiap strategi investasi.

d. Jenis aset yang dapat dipilih untuk membentuk subdana wajib memenuhi ketentuan Pasal 21 ayat (2) Keputusan Menteri Keuangan Nomor 424/KMK.06/2003 sebagaimana telah diubah dengan Peraturan Menteri Keuangan Nomor 135/PMK.05/2005.

e. Nilai manfaat yang menjadi hak pemegang polis ditentukan berdasarkan jumlah dan nilai unit subdana untuk yang bersangkutan.

\section{Nilai Aset Subdana}

a. Perusahaan asuransi jiwa wajib menghitung nilai aset untuk setiap subdana berdasarkan nilai wajar.

b. Nilai aset untuk setiap subdana dihitung berdasarkan nilai wajar dari masingmasing jenis aset yang membentuknya.

c. Nilai wajar bagi masing-masing jenis aset sebagaimana dimaksud pada huruf b adalah sebagai berikut:

1) Kas dan bank berdasarkan nilai nominal.

2) Deposito berjangka, termasuk deposit on call dan deposito yang berjangka waktu kurang dari atau sama dengan 1 (satu) bulan, berdasarkan nilai nominal.

3) Sertifikat deposito berdasarkan nilai tunai.

4) Saham adalah sebagai berikut:

a) untuk yang aktif diperdagangkan di Bursa Efek berdasarkan harga pasar yang diperoleh dari informasi harga perdagangan terakhir saham tersebut di Bursa Efek;

b) untuk yang tidak aktif diperdagangkan di Bursa Efek, perusahaan asuransi jiwa wajib menetapkan harga saham tersebut dengan itikad baik dan penuh tanggung jawab dengan mempertimbangkan harga perdagangan sebelumnya atau harga perbandingan saham sejenis.

5) Surat berharga bersifat utang yang diterbitkan oleh perusahaan yaitu obligasi dan Medium Term Note (MTN) adalah sebagai berikut: 
a) untuk yang aktif diperdagangkan di Bursa Efek berdasarkan harga pasar yang diperoleh dari informasi harga perdagangan terakhir surat berharga tersebut di Bursa Efek;

b) untuk yang tidak aktif diperdagangkan di Bursa Efek atau yang diperdagangkan di luar Bursa Efek, perusahaan asuransi jiwa wajib menetapkan harga surat berharga tersebut dengan itikad baik dan penuh tanggung jawab dengan mempertimbangkan harga perdagangan sebelumnya atau harga perbandingan surat berharga sejenis.

6) Unit Penyertaan Reksa Dana berdasarkan nilai aktiva bersih.

7) Surat utang atau surat berharga lainnya yang diterbitkan oleh Pemerintah Indonesia atau Bank Indonesia adalah sebagai berikut:

a) untuk yang aktif diperdagangkan di Bursa Efek berdasarkan harga pasar yang diperoleh dari informasi harga perdagangan terakhir surat utang atau surat berharga lainnya tersebut di Bursa Efek;

b) untuk yang tidak aktif diperdagangkan di Bursa Efek, perusahaan asuransi jiwa wajib menetapkan harga surat utang atau surat berharga lainnya tersebut dengan itikad baik dan penuh tanggung jawab dengan mempertimbangkan harga perdagangan sebelumnya atau harga perbandingan surat utang atau surat berharga lainnya yang sejenis;

c) untuk yang diperdagangkan di luar Bursa Efek berdasarkan harga referensi yang dikeluarkan oleh penyelenggara perdagangan surat utang atau surat berharga lainnya yang diterbitkan oleh Pemerintah Indonesia atau Bank Indonesia, yang telah mendapat izin dari Badan Pengawas Pasar Modal dan Lembaga Keuangan.

d) Perhitungan nilai aset untuk setiap subdana dilakukan setiap hari.

\section{Brosur Pemasaran}

a. Dalam memasarkan produk unit link, perusahaan asuransi jiwa wajib menggunakan brosur yang memuat sekurang-kurangnya hal-hal sebagai berikut:

1) penjelasan umum mengenai manfaat asuransi yang menjelaskan bahwa besar manfaat polis tergantung pada kinerja investasi dan faktor-faktor lain yang mempengaruhi manfaat polis;

2) penjelasan mengenai strategi investasi;

3) uraian mengenai risiko yang ditanggung oleh pemegang polis;

4) rincian seluruh biaya yang dibebankan kepada pemegang polis antara lain terdiri dari biaya akuisisi, biaya pengelolaan, dan biaya mortalita;

5) biaya penarikan dana;

6) uraian mengenai dasar perhitungan manfaat polis;

7) uraian mengenai dasar dan frekuensi penilaian dana; 
8) uraian mengenai hal-hal yang dijamin bagi pemegang polis bila ada, misalnya manfaat kematian minimum yang dijamin, maksimum beban mortalita dan biaya-biaya lainnya, tingkat bunga minimum, nilai tunai minimum, dan manfaat jatuh tempo yang dijamin;

9) ilustrasi pertumbuhan besar manfaat, termasuk manfaat asuransi kematian, atas dasar asumsi yang realistis dan disajikan dalam bentuk grafik atau diagram;

10) uraian mengenai kinerja investasi subdana terkait dalam periode sekurang-kurangnya 5 (lima) tahun terakhir atau dalam periode riil yang telah dijalani bagi perusahaan yang menjual produk tersebut kurang dari 5 (lima) tahun; dan

11) pernyataan yang menegaskan bahwa:

a) nilai manfaat dapat meningkat atau menurun;

b) pertumbuhan besar manfaat sebagaimana dimaksud dalam butir 9) hanya merupakan ilustrasi;

c) kinerja investasi subdana tidak dijamin akan sama dengan kinerja selama periode sebagaimana dimaksud dalam butir 10); dan

d) nilai manfaat dapat lebih kecil dari nilai dana yang diinvestasikan, tergantung pada ada atau tidaknya bagian manfaat yang dijamin.

b. Pernyataan sebagaimana dimaksud dalam huruf a butir 11) wajib dicetak sedemikian rupa sehingga dapat dengan mudah dibaca dan dipahami.

c. Perusahaan asuransi jiwa wajib memberitahukan kepada calon pemegang polis informasi yang tertuang dalam brosur pemasaran disertai risiko yang terkandung dalam strategi investasi.

6. Perusahaan asuransi jiwa wajib menyediakan informasi bagi publik mengenai harga unit subdana yang dikelolanya setiap hari kerja, sekurang-kurangnya dengan menempatkan informasi tersebut pada satu surat kabar harian berbahasa Indonesia yang berperedaran nasional.

7. Polis asuransi untuk produk unit link selain wajib memenuhi ketentuan sebagaimana dimaksud dalam Pasal 8 Keputusan Menteri Keuangan Nomor 422/KMK.06/2003 tentang Penyelenggaraan Usaha Perusahaan Asuransi dan Perusahaan Reasuransi, sekurang-kurangnya juga wajib memuat informasi atau ketentuan sebagai berikut:

a. jangka waktu dimana pemegang polis dimungkinkan untuk mengembalikan polis kepada perusahaan asuransi jiwa dan menerima pengembalian premi yang sudah dibayarkan setelah dikurangi biaya administrasi;

b. strategi investasinya;

c. pembentukan unit yang bersumber dari premi;

d. metode dan frekuensi perhitungan nilai unit;

e. hak pemegang polis untuk memilih satu atau lebih subdana;

f. hak pemegang polis untuk memindahkan dana dari satu produk unit link ke produk unit link yang lain; 
g. hak pemegang polis untuk tidak membayar premi dalam suatu periode tertentu; dan

h. rincian seluruh biaya yang dibebankan kepada pemegang polis antara lain terdiri dari biaya akuisisi, biaya pengelolaan, dan biaya mortalita.

8. Pelaporan Perkembangan Dana

a. Perusahaan asuransi jiwa wajib melaporkan perkembangan dana hak pemegang polis kepada pemegang polis yang bersangkutan sekurangkurangnya sekali dalam satu tahun.

b. Pelaporan perkembangan dana sebagaimana dimaksud dalam huruf a memuat sekurang-kurangnya hal-hal sebagai berikut:

1) nilai dan harga unit subdana per tanggal valuasi untuk periode berjalan dan periode lalu;

2) nilai dan harga unit subdana yang dibeli dalam periode berjalan;

3) nilai dan harga unit subdana yang dijual dalam periode berjalan;

4) rincian seluruh biaya yang dibebankan kepada pemegang polis antara lain terdiri dari biaya akuisisi, biaya pengelolaan, biaya mortalita dan biaya pertanggungan tambahan;

5) besar uang pertanggungan kematian pada akhir periode berjalan;

6) nilai tunai neto pada akhir periode berjalan;

7) saldo pinjaman polis, bila ada, pada akhir periode berjalan;

8) hasil investasi bersih untuk jangka waktu sekurang-kurangnya 5 (lima) tahun terakhir, bila tersedia, untuk setiap subdana; dan

9) rincian komposisi investasi untuk setiap subdana per tanggal pelaporan.

9. Seorang agen atau tenaga pemasaran dapat memasarkan produk unit link apabila yang bersangkutan memenuhi ketentuan sebagai berikut:

a. memiliki sertifikasi keagenan dari Asosiasi Asuransi Jiwa Indonesia; dan

b. memiliki sertifikasi keagenan khusus untuk produk unit link dari Asosiasi Asuransi Jiwa Indonesia.

\section{Inflasi}

Menurut Hubbard ( 2006, p624-625 ), inflasi bisa diukur dengan menggunakan CPI ( Consumer Price Index ).

Consumer Price Index (CPI) is an average of the prices of the goods and services purchased by the typical family. One Year is chosen as the base year, and the value of the CPI is set equal to 100 for that year. In any year other than base year, the CPI is equal to the ratio of the dollar amount necessary to buy the market basket of goods in that year divided by the dollar amount necessary to buy the market basket of goods in the base year, multiplied by 100. Because the CPI measures the cost to the typical family to buy a representative basket of goods and services, it sometimes referred to as the cost-of living index.

The CPI is the most widely use measure of inflation. Policy makers use the CPI to track the state of the economy. Businesses use it to help set the prices of their products and the wages and salaries of their employees 


\section{Market Model}

Menurut Bodie, Kane dan Marcus ( 2008, p308 ) market model adalah

Formally, the market model states that the return "surprise" of any security is proportional to the return surprise of the market, plus a firm-specific surprise :

$r_{i}-E\left(r_{i}\right)=\beta_{i}[r M-E(r M)]+e_{i}$

This eqution divides returns into firm-specific and systematic components somewhat differently from the index model. If the CAPM is valid, however, you can confirm that, substituting for E(ri) from equation, the nmarket model equation becomes idfentical to the index model.

For this reason the terms "index model" and "market model" often are used interchangeably.

Market Model Another version of ther index model that breaks down return uncertainty into systematic and nonsystematic component

\section{Investasi}

Hampir setiap hari kata "investasi" diperbincangkan banyak orang, tetapi sebenarnya yang dimaksud dengan istilah tersebut menurut Malkiel (1991) dalam bukunya, A Random Walk Down Wall Street, including A Life-Cycle Guide to Personal Investing adalah "Method of purchasing asset in order to gain profit in the form of reasonably predictable income (dividen, interest or rentals) and/or appreciation over the long term." Sejumlah hasil penanaman dana dalam jumlah tertentu yang sangat ditentukan oleh kemampuan dalam memprediksi masa depan. Memprediksi masa depan inilah yang kemudian membedakan istilah "investasi" dan "spekulasi". Pengertian tersebut selanjutnya dipertajam oleh Reilly (1992) dalam bukunya, Investments, dengan memasukkan unsur risiko sebagai sebuah kompensasi. "Current commitment of dollars for period of time in order to derive future payments that will compensate the investor for (1) the time the fund are committed (2) the expected rate of inflation and (3) the uncertainty of the future payments."

Menurut Jones (1999) dalam bukunya, Investment Analysis and Management, yang dimaksud dengan investasi adalah : "An Investment can be defined as the commitment of funds to one or more assets that will be held over some future time period." 


\section{METODOLOGI PERANCANGAN}

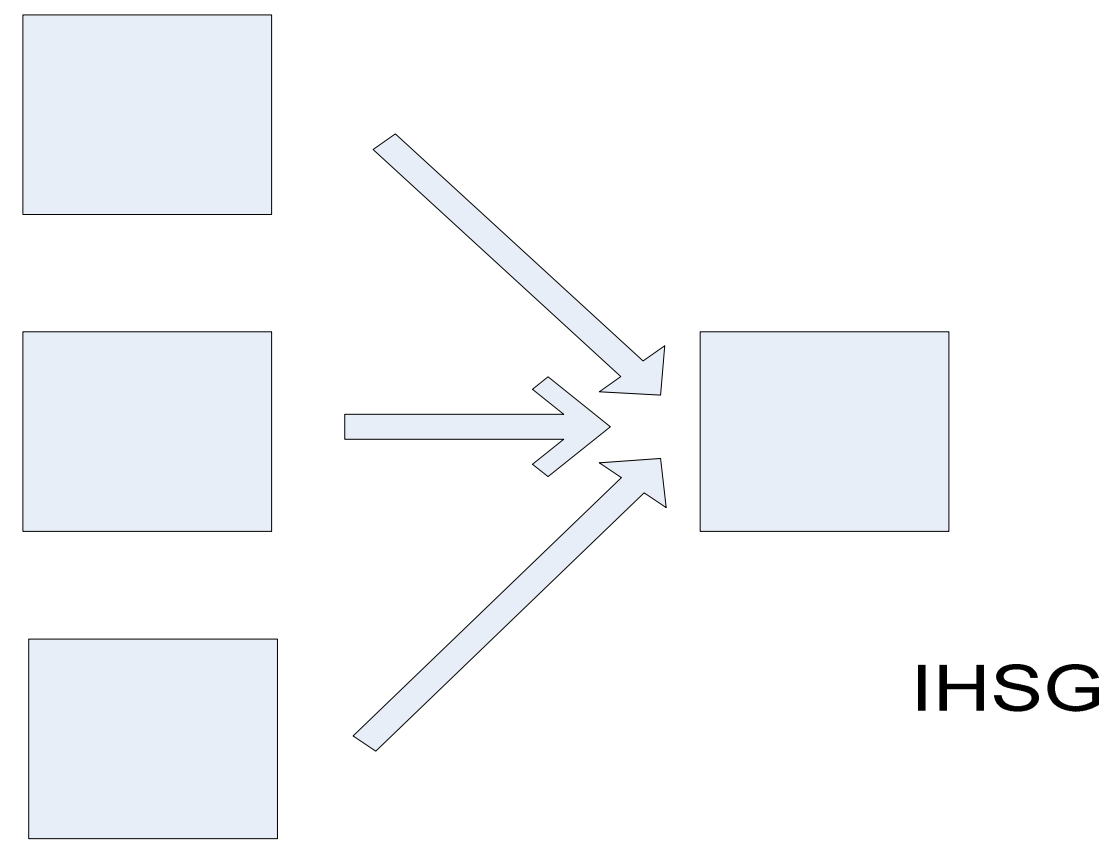

Gambar 1. Imbal Hasil Unitlink

Analisis data merupakan hal yang penting untuk dilakukan dalam melakukan sebuah penelitian. Dengan melakukan analisis yang tepat maka data dapat menjadi berarti dan bermanfaat untuk memecahkan masalah yang dihadapi.

Analisis dilakukan melalui dua tahapan, yaitu :

1. Pengumpulan data Index Inflasi secara bulanan selama periode Januari 2007Desember 2007 yang diakses melalui website http://www.bi.go.id, data BI Rate secara bulanan selama periode Januari 2007- Dsember 2007 juga diakses melalui website http://www.bi.go.id, dan data IHSG harian selama periode Januprifflä-Besember 2007 yang diakses melalui website http://finance.yahoo.com

2. Pengumpulan data NAB dari produk-produk unitlink berbasis saham. Data yang dibutuhkan adalah data NAB harian dari unitlink berbasis saham periode Januari 2007 sampai dengan Desember 2007

3. Analisis Regresi Berganda

Analisis regresi berganda digunakan untuk meramalkan seberapa jauh pengaruh dari variabel-variabel independen terhadap variabel dependennya.

Regresi berganda dilakukan karena terdapat lebih dari satu variabel independen, yaitu : IHSG, Inflasi, BI Rate.

$Y=\beta_{0}+\beta_{1} X_{1}+\beta_{2} X_{2}+\beta_{3} X_{3}$

di mana :

$\mathrm{Y}=$ return/imbal hasil produk unitlink 


$$
\begin{aligned}
& \beta_{0}=\text { intersep } \\
& \beta_{1}=\text { IHSG } \\
& \beta_{2}=\text { Inflasi }(\text { cpi }) \\
& \left.\beta_{3}=\text { BI Rate ( interest }\right)
\end{aligned}
$$

\section{HASIL}

Perlu dilakukan sebuah pemodelan yang menyatakan / menggambarkan hubungan antara IHSG, BI Rate, dan inflasi terhadap imbal hasil produk Unitlink yang diuji. Pemodelan dilakukan dengan menggunakan Regresi Linear Beganda ( Multiple Linear Regression ) dikarenakan terdapatnya beberapa variabel independen.

Variabel-variabel independen tersebut adalah :

IHSG, BI Rate dan inflasi.

Sehingga persamaannya adalah sebagai berikut :

$$
\begin{aligned}
& Y=\beta_{0}+\beta_{1} X_{1}+\beta_{2} X_{2}+\beta_{3} X_{3} \\
& \text { di mana : } \\
& Y=\text { return/imbal hasil produk unitlink } \\
& \beta_{0}=\text { intersep } \\
& \beta_{1}=\text { IHSG } \\
& \beta_{2}=\text { Inflasi } \\
& \beta_{3}=\text { BI Rate }
\end{aligned}
$$

Setelah dilakukan perhitungan dengan bantuan software SPSS didapatkan hasil sebagai berikut :

$$
\begin{aligned}
& \mathrm{Y}_{1}: \quad 0.003+1.012 \mathrm{X}_{1}+0.001 \mathrm{X}_{2}-0.040 \mathrm{X}_{3} \\
& \mathrm{Y}_{2}:-0.111+0.830 \mathrm{X}_{1}+1.015 \mathrm{X}_{2}+0.499 \mathrm{X}_{3} \\
& \mathrm{Y}_{3}:-0.005+0.257 \mathrm{X}_{1}+0.098 \mathrm{X}_{2}+0.010 \mathrm{X}_{3} \\
& \mathrm{Y}_{4}: 0.004+0.998 \mathrm{X}_{1}-0.015 \mathrm{X}_{2}-0.021 \mathrm{X}_{3} \\
& \mathrm{Y}_{5}: 0.008+0.997 \mathrm{X}_{1}-0.095 \mathrm{X}_{2}-0.017 \mathrm{X}_{3} \\
& \mathrm{Y}_{6}: 0.007+0.956 \mathrm{X}_{1}-0.104 \mathrm{X}_{2}+0.003 \mathrm{X}_{3} \\
& \mathrm{Y}_{1}=\text { imbal hasil produk Unitlink BNI-Life } \\
& \mathrm{Y}_{2}=\text { imbal hasil produk Unitlink Allianz } \\
& \mathrm{Y}_{3}=\text { imbal hasil produk Unitlink Prudential } \\
& \mathrm{Y}_{4}=\text { imbal hasil produk Unitlink AXA } \\
& \mathrm{Y}_{5}=\text { imbal hasil produk Unitlink Great Eastern Life } \\
& \mathrm{Y}_{6}=\text { imbal hasil produk Unitlink Sun Life }
\end{aligned}
$$


Hasil perhitungan $\mathrm{R}^{2}$

Tabel 1. Model Summary BNI Life

\begin{tabular}{|l|c|r|r|r|}
\hline Model & R & R Square & $\begin{array}{c}\text { Adjusted } \\
\text { R Square }\end{array}$ & $\begin{array}{c}\text { Std. Error of } \\
\text { the Estimate }\end{array}$ \\
\hline 1 & $.934(\mathrm{a})$ & .873 & .871 & .0058043 \\
\hline
\end{tabular}

a Predictors: (Constant), BI RATE, IHSG, CPI

b Dependent Variable: NAB

Nilai $\mathrm{R}$ Square $=0.873$ menandakan bahwa perubahan variable independent imbal hasil dapat dijelaskan sebesar $87.3 \%$ oleh variable-variabel bebas independent IHSG, BI Rate dan Inflasi dan $12.7 \%$ dijelaskan oleh berbagai faktor lain yang tidak termasuk dalam model penelitian.

Tabel 2. Model Summary Allianz

\begin{tabular}{|l|c|r|r|r|}
\hline Model & R & R Square & $\begin{array}{l}\text { Adjusted } \\
\text { R Square }\end{array}$ & $\begin{array}{l}\text { Std. Error of } \\
\text { the Estimate }\end{array}$ \\
\hline 1 & $.929(\mathrm{a})$ & .864 & .858 & .0046961 \\
\hline
\end{tabular}

a Predictors: (Constant), BI RATE, IHSG, CPI

b Dependent Variable: NAB

Nilai $\mathrm{R}$ Square $=0.864$ menandakan bahwa perubahan variable independent imbal hasil dapat dijelaskan sebesar $86.4 \%$ oleh variable-variabel bebas independent IHSG, BI Rate dan Inflasi dan $13.6 \%$ dijelaskan oleh berbagai faktor lain yang tidak termasuk dalam model penelitian.

Tabel 3. Model Summary Prudential

\begin{tabular}{|l|c|r|r|r|}
\hline Model & R & R Square & $\begin{array}{c}\text { Adjusted } \\
\text { R Square }\end{array}$ & $\begin{array}{r}\text { Std. Error of } \\
\text { the Estimate }\end{array}$ \\
\hline 1 & $.246(\mathrm{a})$ & .061 & .042 & .0189983 \\
\hline
\end{tabular}

a Predictors: (Constant), BI RATE, IHSG, CPI

b Dependent Variable: NAB

Nilai R Square $=0.061$ menandakan bahwa perubahan variable independent imbal hasil dapat dijelaskan sebesar $6.1 \%$ oleh variable-variabel bebas independent IHSG, BI Rate dan Inflasi dan $93.9 \%$ dijelaskan oleh berbagai faktor lain yang tidak termasuk dalam model penelitian.

Tabel 4. Model Summary AXA

\begin{tabular}{|l|c|r|r|r|}
\hline Model & R & R Square & $\begin{array}{l}\text { Adjusted } \\
\text { R Square }\end{array}$ & $\begin{array}{c}\text { Std. Error of } \\
\text { the Estimate }\end{array}$ \\
\hline 1 & $.973(\mathrm{a})$ & .946 & .945 & .0035934 \\
\hline
\end{tabular}

a Predictors: (Constant), BI RATE, IHSG, CPI

b Dependent Variable: NAB 
Nilai R Square $=0.946$ menandakan bahwa perubahan variable independent imbal hasil dapat dijelaskan sebesar $94.6 \%$ oleh variable-variabel bebas independent IHSG, BI Rate dan Inflasi dan 5.4\% dijelaskan oleh berbagai faktor lain yang tidak termasuk dalam model penelitian.

Tabel 5. Model Summary Great Eastern Life

\begin{tabular}{|l|c|r|r|r|}
\hline Model & R & R Square & $\begin{array}{c}\text { Adjusted } \\
\text { R Square }\end{array}$ & $\begin{array}{r}\text { Std. Error of } \\
\text { the Estimate }\end{array}$ \\
\hline 1 & $.932(\mathrm{a})$ & .868 & .866 & .0061271 \\
\hline
\end{tabular}

a Predictors: (Constant), BI RATE, IHSG, CPI

b Dependent Variable: NAB

Nilai $\mathrm{R}$ Square $=0.868$ menandakan bahwa perubahan variable independent imbal hasil dapat dijelaskan sebesar $86.8 \%$ oleh variable-variabel bebas independent IHSG, BI Rate dan Inflasi dan $13.2 \%$ dijelaskan oleh berbagai faktor lain yang tidak termasuk dalam model penelitian.

Tabel 6. Model Summary SunLife

\begin{tabular}{|l|c|r|r|r|}
\hline Model & R & R Square & $\begin{array}{c}\text { Adjusted } \\
\text { R Square }\end{array}$ & $\begin{array}{c}\text { Std. Error of } \\
\text { the Estimate }\end{array}$ \\
\hline 1 & $.988(\mathrm{a})$ & .976 & .976 & .0022424 \\
\hline
\end{tabular}

a Predictors: (Constant), BNI RATE, IHSG, CPI

b Dependent Variable: NAB

Nilai $\mathrm{R}$ Square $=0.976$ menandakan bahwa perubahan variable independent imbal hasil dapat dijelaskan sebesar 97.6\% oleh variable-variabel bebas independent IHSG, BI Rate dan Inflasi dan $2.4 \%$ dijelaskan oleh berbagai faktor lain yang tidak termasuk dalam model penelitian.

Secara keseluruhan dari dari perhitungan R2 menunjukkan bahwa nilai $\mathrm{R}^{2}$ terbesar adalah Produk Sun Life sebesar 0.976, dengan nilai terkecil adalah Prudential sebesar 0.061

$\mathrm{H}_{0}$ : Tidak ada pengaruh antara nilai imbal hasil/return unitlink dengan variabel-variabel independen yaitu IHSG, Inflasi dan BI Rate

$\mathrm{H}_{1}$ : Ada pengaruh antara nilai imbal hasil/return unitlink dengan variabel-variabel independen yaitu IHSG, Inflasi dan BI Rate

$\mathrm{H}_{0}$ ditolak jika p-value / Sig. yang didapatkan adalah lebih kecil dari alpha yang telah dipilih yaitu $0.05(5 \%)$ 
Tabel 7. ANOVA BNI Life

\begin{tabular}{|ll|r|r|r|r|l|}
\hline Model & & $\begin{array}{c}\text { Sum of } \\
\text { Squares }\end{array}$ & Df & Mean Square & F & Sig. \\
\hline 1 & Regression & .056 & 3 & .019 & 552.243 & $.000(\mathrm{a})$ \\
& Residual & .008 & 241 & .000 & & \\
& Total & .064 & 244 & & & \\
\hline
\end{tabular}

a Predictors: (Constant), BI RATE, IHSG, CPI

b Dependent Variable: NAB

Secara simultan, nilai Sig. yang dihasilkan adalah 0 yang lebih kecil dari 0.05 yang menandakan bahwa secara simultan ada pengaruh dari masing-masing variable independent IHSG, BI Rate dan Inflasi terhadap nilai imbal hasil.

Tabel 8. ANOVA Allianz

\begin{tabular}{|c|c|c|c|c|c|c|}
\hline Model & & $\begin{array}{c}\text { Sum of } \\
\text { Squares }\end{array}$ & $\mathrm{df}$ & Mean Square & $\mathrm{F}$ & Sig. \\
\hline \multirow[t]{3}{*}{1} & Regression & .010 & 3 & \multirow{3}{*}{$\begin{array}{l}.003 \\
.000\end{array}$} & \multirow[t]{3}{*}{158.670} & \multirow[t]{3}{*}{$.000(a)$} \\
\hline & Residual & .002 & 75 & & & \\
\hline & Total & .012 & 78 & & & \\
\hline
\end{tabular}

a Predictors: (Constant), BI RATE, IHSG, CPI

b Dependent Variable: NAB

Secara simultan, nilai Sig. yang dihasilkan adalah 0 yang lebih kecil dari 0.05 yang menandakan bahwa secara simultan ada pengaruh dari masing-masing variable independent IHSG, BI Rate dan Inflasi terhadap nilai imbal hasil.

Tabel 9. ANOVA Prudential

\begin{tabular}{|ll|r|r|r|r|r|}
\hline Model & & $\begin{array}{r}\text { Sum of } \\
\text { Squares }\end{array}$ & Df & Mean Square & F & \multicolumn{1}{c|}{ Sig. } \\
\hline 1 & Regression & .004 & 3 & .001 & 3.296 & $.022(\mathrm{a})$ \\
& Residual & .055 & 153 & .000 & & \\
& Total & .059 & 156 & & & \\
\hline
\end{tabular}

a Predictors: (Constant), BI RATE, IHSG, CPI

b Dependent Variable: NAB

Secara simultan, nilai Sig. yang dihasilkan adalah 0.022 yang lebih kecil dari 0.05 yang menandakan bahwa secara simultan ada pengaruh dari masing-masing variable independent IHSG, BI Rate dan Inflasi terhadap nilai imbal hasil. 
Tabel 10. ANOVA AXA

\begin{tabular}{|ll|r|r|r|r|r|}
\hline Model & & $\begin{array}{c}\text { Sum of } \\
\text { Squares }\end{array}$ & Df & Mean Square & F & Sig. \\
\hline 1 & Regression & .054 & 3 & .018 & 1400.795 & .000 (a) \\
& Residual & .003 & 241 & .000 & & \\
& Total & .057 & 244 & & & \\
\hline
\end{tabular}

a Predictors: (Constant), BI RATE, IHSG, CPI

b Dependent Variable: NAB

Secara simultan, nilai Sig. yang dihasilkan adalah 0 yang lebih kecil dari 0.05 yang menandakan bahwa secara simultan ada pengaruh dari masing-masing variable independent IHSG, BI Rate dan Inflasi terhadap nilai imbal hasil.

Tabel 11. ANOVA Great Eastern Life

\begin{tabular}{|ll|r|r|r|r|l|}
\hline Model & & $\begin{array}{c}\text { Sum of } \\
\text { Squares }\end{array}$ & df & Mean Square & F & Sig. \\
\hline 1 & Regression & .045 & 3 & .015 & 400.198 & $.000(\mathrm{a})$ \\
& Residual & .007 & 182 & .000 & & \\
& Total & .052 & 185 & & & \\
\hline
\end{tabular}

a Predictors: (Constant), BI RATE, IHSG, CPI

b Dependent Variable: NAB

Secara simultan, nilai Sig. yang dihasilkan adalah 0 yang lebih kecil dari 0.05 yang menandakan bahwa secara simultan ada pengaruh dari masing-masing variable independent IHSG, BI Rate dan Inflasi terhadap nilai imbal hasil.

Tabel 12. ANOVA SunLife

\begin{tabular}{|ll|r|r|r|r|l|}
\hline Model & \multicolumn{1}{|c|}{$\begin{array}{c}\text { Sum of } \\
\text { Squares }\end{array}$} & df & Mean Square & F & Sig. \\
\hline 1 & Regression & .050 & 3 & .017 & 3342.229 & $.000(\mathrm{a})$ \\
& Residual & .001 & 244 & .000 & & \\
& Total & .052 & 247 & & & \\
\hline
\end{tabular}

a Predictors: (Constant), BNI RATE, IHSG, CPI

b Dependent Variable: NAB

Secara simultan, nilai Sig. yang dihasilkan adalah 0 yang lebih kecil dari 0.05 yang menandakan bahwa secara simultan ada pengaruh dari masing-masing variable independent IHSG, BI Rate dan Inflasi terhadap nilai imbal hasil. 
Dengan demikian dapat disimpulkan bahwa Hipotesis $\mathrm{H}_{0}$ untuk 6 perusahaan tersebut ditolak atau dengan kata lain, ada hubungan antara IHSG, Inflasi dan BI Rate terhadap nilai imbal hasil/return dari seluruh 6 produk unitlink berbasis saham tersebut

Sedangkan untuk mengetahui berapa besar pengaruh dari masing-masing variabel independen terhadap variabel dependen, dilakukan uji t dengan didapatkan hasil sebagai berikut :

Tabel 13. Koefisien Variabel Independen BNI Life

\begin{tabular}{|c|c|c|c|c|c|c|c|c|}
\hline \multirow{2}{*}{\multicolumn{2}{|c|}{ Model }} & \multicolumn{2}{|c|}{$\begin{array}{l}\text { Unstandardized } \\
\text { Coefficients }\end{array}$} & \multirow{2}{*}{$\begin{array}{c}\text { Standardized } \\
\text { Coefficients } \\
\text { Beta } \\
\end{array}$} & \multirow[t]{2}{*}{$\mathrm{t}$} & \multirow[t]{2}{*}{ Sig. } & \multicolumn{2}{|c|}{$\begin{array}{c}\text { Collinearity } \\
\text { Statistics }\end{array}$} \\
\hline & & B & Std. Error & & & & Tolerance & VIF \\
\hline \multirow[t]{4}{*}{1} & (Constant) & .003 & .012 & & .207 & .836 & & \\
\hline & IHSG & 1.012 & .025 & .935 & 40.677 & .000 & .998 & 1.002 \\
\hline & CPI & .001 & .115 & .000 & .006 & .995 & .871 & 1.149 \\
\hline & BI Rate & -.040 & .089 & -.011 & -.448 & .654 & .870 & 1.149 \\
\hline
\end{tabular}

Secara parsial, IHSG memberikan pengaruh paling besar terhadap produk unitlink BNI Life, BI Rate dan Inflasi tidak memberikan pengaruh.

Tabel 14. Koefisien Variabel Independen Allianz

\begin{tabular}{|c|c|c|c|c|c|c|c|c|}
\hline & \multirow[t]{2}{*}{ Model } & \multicolumn{2}{|c|}{$\begin{array}{c}\text { Unstandardized } \\
\text { Coefficients }\end{array}$} & \multirow{2}{*}{$\begin{array}{c}\text { Standardized } \\
\text { Coefficients } \\
\text { Beta } \\
\end{array}$} & \multirow[t]{2}{*}{$\mathrm{t}$} & \multirow[t]{2}{*}{ Sig. } & \multicolumn{2}{|c|}{ Collinearity Statistics } \\
\hline & & B & Std. Error & & & & Tolerance & VIF \\
\hline \multirow[t]{4}{*}{1} & (Constant) & -.111 & .064 & & -1.732 & .087 & & \\
\hline & IHSG & .830 & .039 & .925 & 21.511 & .000 & .982 & 1.019 \\
\hline & CPI & 1.015 & .645 & .085 & 1.574 & .120 & .628 & 1.593 \\
\hline & BI Rate & .499 & .330 & .081 & 1.511 & .135 & .630 & 1.588 \\
\hline
\end{tabular}

Secara parsial, IHSG memberikan pengaruh paling besar terhadap produk unitlink Allianz, BI Rate dan Inflasi tidak memberikan pengaruh.

Tabel 15. Koefisien Variabel Independen Prudential

\begin{tabular}{|c|c|c|c|c|c|c|c|c|}
\hline \multirow{2}{*}{\multicolumn{2}{|c|}{ Model }} & \multicolumn{2}{|c|}{$\begin{array}{c}\text { Unstandardized } \\
\text { Coefficients }\end{array}$} & \multirow{2}{*}{$\begin{array}{c}\text { Standardized } \\
\text { Coefficients } \\
\text { Beta } \\
\end{array}$} & \multirow[b]{2}{*}{$\mathrm{t}$} & \multirow[b]{2}{*}{ Sig. } & \multicolumn{2}{|c|}{ Collinearity Statistics } \\
\hline & & B & Std. Error & & & & Tolerance & VIF \\
\hline \multirow[t]{4}{*}{1} & (Constant) & -.005 & .053 & & -.098 & .922 & & \\
\hline & IHSG & .257 & .082 & .245 & 3.126 & .002 & .997 & 1.003 \\
\hline & CPI & .098 & .536 & .015 & .182 & .856 & .894 & 1.119 \\
\hline & BI RATE & .010 & .353 & .002 & .029 & .977 & .895 & 1.117 \\
\hline
\end{tabular}


Secara parsial, IHSG memberikan pengaruh paling besar terhadap produk unitlink Prudential, BI Rate dan Inflasi tidak memberikan pengaruh.

Tabel 16. Koefisien Variabel Independen AXA

\begin{tabular}{|c|c|c|c|c|c|c|c|c|}
\hline \multirow[b]{2}{*}{ Model } & & \multicolumn{2}{|c|}{$\begin{array}{l}\text { Unstandardized } \\
\text { Coefficients }\end{array}$} & \multirow{2}{*}{$\begin{array}{c}\text { Standardized } \\
\text { Coefficients } \\
\text { Beta }\end{array}$} & \multirow[b]{2}{*}{$\mathrm{t}$} & \multirow[b]{2}{*}{ Sig. } & \multicolumn{2}{|c|}{ Collinearity Statistics } \\
\hline & & B & Std. Error & & & & Tolerance & VIF \\
\hline 1 & (Constant) & $\begin{array}{r}3.518 \mathrm{E}- \\
03\end{array}$ & .008 & & .460 & .646 & & \\
\hline & IHSG & .998 & .015 & .973 & 64.782 & .000 & .998 & 1.002 \\
\hline & CPI & -.015 & .071 & -.003 & -.211 & .833 & .871 & 1.148 \\
\hline & BI RATE & -.021 & .055 & -.006 & -.387 & .699 & .871 & 1.148 \\
\hline
\end{tabular}

Secara parsial, IHSG memberikan pengaruh paling besar terhadap produk unitlink AXA, BI Rate dan Inflasi tidak memberikan pengaruh.

Tabel 17. Koefisien Variabel Independen Great Eastern Life

\begin{tabular}{|c|c|c|c|c|c|c|c|c|}
\hline \multirow{2}{*}{\multicolumn{2}{|c|}{ Model }} & \multicolumn{2}{|c|}{$\begin{array}{c}\text { Unstandardized } \\
\text { Coefficients }\end{array}$} & \multirow{2}{*}{$\begin{array}{c}\text { Standardized } \\
\text { Coefficients } \\
\text { Beta }\end{array}$} & \multirow[b]{2}{*}{$\mathrm{t}$} & \multirow[b]{2}{*}{ Sig. } & \multicolumn{2}{|c|}{ Collinearity Statistics } \\
\hline & & B & Std. Error & & & & Tolerance & VIF \\
\hline \multirow[t]{4}{*}{1} & (Constant) & .008 & .013 & & .583 & .560 & & \\
\hline & IHSG & .997 & .029 & .933 & 34.622 & .000 & .997 & 1.003 \\
\hline & CPI & -.095 & .137 & -.019 & -.699 & .486 & .978 & 1.023 \\
\hline & BI RATE & -.017 & .106 & -.004 & -.164 & .870 & .981 & 1.020 \\
\hline
\end{tabular}

Secara parsial, IHSG memberikan pengaruh paling besar terhadap produk unitlink Great Eastern Life, BI Rate dan Inflasi tidak memberikan pengaruh.

Tabel 18. Koefisien Variabel Independen SunLife

\begin{tabular}{|c|c|c|c|c|c|c|c|c|}
\hline \multirow{2}{*}{\multicolumn{2}{|c|}{ Model }} & \multicolumn{2}{|c|}{$\begin{array}{l}\text { Unstandardized } \\
\text { Coefficients }\end{array}$} & \multirow{2}{*}{$\begin{array}{c}\text { Standardized } \\
\text { Coefficients } \\
\text { Beta } \\
\end{array}$} & \multirow[b]{2}{*}{$\mathrm{t}$} & \multirow[b]{2}{*}{ Sig. } & \multicolumn{2}{|c|}{ Collinearity Statistics } \\
\hline & & B & Std. Error & & & & Tolerance & VIF \\
\hline \multirow[t]{4}{*}{1} & (Constant) & $\begin{array}{r}6.552 \mathrm{E}- \\
03\end{array}$ & .005 & & 1.380 & .169 & & \\
\hline & IHSG & .956 & .010 & .988 & 100.062 & .000 & .998 & 1.002 \\
\hline & CPI & -.104 & .045 & -.025 & -2.315 & .021 & .868 & 1.152 \\
\hline & BI RATE & $\begin{array}{r}3.571 \mathrm{E}- \\
03\end{array}$ & .034 & .001 & .106 & .915 & .868 & 1.152 \\
\hline
\end{tabular}


Secara parsial, IHSG memberikan pengaruh paling besar terhadap produk unitlink Sunlife, diikuti oleh Inflasi dan BI Rate tidak memberikan pengaruh.

Nilai t dari variabel Inflasi yang negatif menunjukkan bila inflasi mengalami kenaikan maka imbal hasil atau return dari unitlink Sunlife akan mengalami penurunan.

\section{KESIMPULAN}

Berdasarkan hasil analisa dapat diambil beberapa kesimpulan :

1. Secara simultan ada pengaruh antara fluktuasi IHSG ( Indeks Harga Saham Gabungan ), Inflasi dan BI Rate ( Suku bunga ) terhadap imbal hasil / return dari produk unitlink berbasis saham untuk BNI Life.

2. Secara simultan ada pengaruh antara fluktuasi IHSG ( Indeks Harga Saham Gabungan ), Inflasi dan BI Rate ( Suku bunga ) terhadap imbal hasil / return dari produk unitlink berbasis saham untuk Allianz.

3. Secara simultan ada pengaruh antara fluktuasi IHSG ( Indeks Harga Saham Gabungan ), Inflasi dan BI Rate ( Suku bunga ) terhadap imbal hasil / return dari produk unitlink berbasis saham untuk Prudential.

4. Secara simultan ada pengaruh antara fluktuasi IHSG ( Indeks Harga Saham Gabungan ), Inflasi dan BI Rate ( Suku bunga ) terhadap imbal hasil / return dari produk unitlink berbasis saham untuk AXA.

5. Secara simultan ada pengaruh antara fluktuasi IHSG ( Indeks Harga Saham Gabungan ), Inflasi dan BI Rate ( Suku bunga ) terhadap imbal hasil / return dari produk unitlink berbasis saham untuk Great Eastern Life.

6. Secara simultan ada pengaruh antara fluktuasi IHSG ( Indeks Harga Saham Gabungan ), Inflasi dan BI Rate ( Suku bunga ) terhadap imbal hasil / return dari produk unitlink berbasis saham untuk SunLife.

7. Secara parsial, IHSG berpengaruh paling signifikan terhadap imbal hasil produk unitlink BNI Life dan BI Rate dan Inflasi tidak berpengaruh signifikan.

8. Secara parsial, IHSG berpengaruh paling signifikan terhadap imbal hasil produk unitlink Allianz dan BI Rate dan Inflasi tidak berpengaruh signifikan.

9. Secara parsial, IHSG berpengaruh paling signifikan terhadap imbal hasil produk unitlink Prudential dan BI Rate dan Inflasi tidak berpengaruh signifikan.

10. Secara parsial, IHSG berpengaruh paling signifikan terhadap imbal hasil produk unitlink AXA dan BI Rate dan Inflasi tidak berpengaruh signifikan.

11. Secara parsial, IHSG berpengaruh paling signifikan terhadap imbal hasil produk unitlink Great Eastern Life dan BI Rate dan Inflasi tidak berpengaruh signifikan.

12. Secara parsial, IHSG berpengaruh paling signifikan terhadap imbal hasil produk unitlink SunLife diikuti oleh Inflasi dan BI Rate tidak berpengaruh signifikan. 


\section{DAFTAR PUSTAKA}

Baltagi, Badi H. (2001). Econometric Analysis of Panel Data. $2^{\text {nd }}$ ed. New York: John Wiley $\&$ Sons.

Bodie-Kane-Marcus. (2008). Investments. $7^{\text {th }}$ Ed. McGraw-Hill.

Eko P. Pratomo \& Ubaidillah Nugraha. (2005). Reksa Dana, Solusi Perencanaan Investasi di Era Modern. Jakarta: PT. Gramedia Pustaka Utama.

Fardiansyah, Tedy. (2003). Smart Investment for Ordinary People. Jakarta: Elex Media Komputindo.

Gujarati, Damodar N. (1992). Essentials of Econometrics. New York: McGraw-Hill.

Hubbard, R. Glenn \& O’Brien, Anthony Patrick. (2006). Economics. Pearson International Edition.

Japari, Antony. (2005). Solusi Cerdas Keuangan Keluarga. Jakarta: Jagadnita Publisihing.

Jones, C.P. (1999). Investment : Analysis and Management, $6^{\text {th }}$ Edition. New York: John Wiley \& Sons Inc.

Keputusan Ketua Badan Pengawas Pasar Modal Dan Lembaga Keuangan Nomor KEP104/BL/2006 Tentang Produk Unitlink.

Levine, David M., Stephan, David, Krehbiel, Timothy C., \& Berenson, Mark L., (2005). Statistics for Managers Using Microsoft Excel. $4^{\text {ed }}$ Ed. Pearson, Prentice Hall.

Malkiel, Burton G. (1991). A Random Walk Down Wall Street, including A Life-Cycle Guide to Personel Investing., 1991: W.W. Norton \& Company.

Reilly, Frank K. (1992). Investments. $3^{\text {rd }}$ Edition. Orlando: The Dryden Press International Edition.

Santoso, Singgih (2001). SPSS Versi 10. Jakarta: Elex Media Komputindo.

Sembel, Roy Ichsan, Muhamad, \& Lubis, Parpudi. (2004). Wisdom for Ordinary People Series Family Financial Planning Series Smart Investment and Insurance Protection for Ordinary Family. Jakarta: Elex Media Komputindo.

Undang-Undang Republik Indonesia Nomor 2 Tahun 1992 Tentang Usaha Perasuransian

Undang-Undang Republik Indonesia Nomor 8 Tahun 1995 Tentang Pasar Modal 
http://www.bei.co.id diakses 19 Agustus 2008

http://www.prudential.co.id diakses 19 Agustus 2008

http://www.bni-life.co.id diakses 19 Agustus 2008

http://www.axa-life.co.id diakses 19 Agustus 2008

http://www.sunlife.co.id diakses 19 Agustus 2008

http://www.lifeisgreat.co.id diakses 19 Agustus 2008

http://www.allianz.co.id diakses 19 Agustus 2008 